\title{
Evaluation of Antioxidant Capacity and Identification of Bioactive Compounds of Crude Methanol Extracts of Caesalpinia pulcherrima (L.) Swartz
}

\author{
G. L. T. DELA TORRE* E. C. AROLLADO ${ }^{1}$, A. A. ATIENZA² AND R. A. M. MANALO
}

Institute of Pharmaceutical Sciences, National Institutes of Health, ${ }^{1}$ Department of Pharmacy, College of Pharmacy, ${ }^{2}$ Department of Basic Health Sciences, College of Dentistry, University of the Philippines-Manila, Ermita, Manila-1000, Philippines

\section{Dela Torre, et al.: Antioxidant Capacity of $C$. pulcherrima}

\begin{abstract}
The study was conducted to determine the antioxidant capacity, expressed as half maximal inhibitory concentration, $\mathrm{IC}_{50}$, of Caesalpinia pulcherrima leaf, flower and seed methanol extracts, and their correlation to their total phenolic, flavonoid and triterpenoid contents. Thin layer chromatographic profiling of the methanol extracts was also conducted followed by ultra-performance liquid chromatography quadruple time-of-flight mass spectrometric analysis for the identification of antioxidant compounds. Based on the quantitative antioxidant assays, all extracts exhibited comparable activity with the reference standard at $800 \mu \mathrm{g} / \mathrm{ml}(\mathrm{P}>0.05)$. Correlation data revealed a strong negative correlation between the $\mathrm{IC}_{50}$ and the total phenolic, flavonoid and triterpenoid contents of the extracts, with statistically significant negative correlations observed between the flavonoids of leaf $(r=-0.997)$ and flower $(r=-0.998)$ with reducing power assay, and triterpenoids of flower $(\mathrm{r}=-\mathbf{1 . 0 0 0})$ with 2,2-diphenyl-1-picrylhydrazyl scavenging assay. Two common spots with antioxidant activity in the thin layer chromatography profiles were subjected to ultra-performance liquid chromatography quadruple time-of-flight mass spectrometric. The majority of compounds were identified in the library as triterpenoids, flavonoids and phenolics, and still a large quantity of compounds were unidentified. Hyperforin, 3-(4'-hydroxy-benzyl)-5,7-dihydroxy-6,8-dimethyl-chroman-4-one and platycodigenin were identified to be the common compounds present on the three plant parts.
\end{abstract}

Key words: Caesalpinia pulcherrima, antioxidant activity, thin layer chromatography, UPLC-QTOF/MS

Herbal medications have been used for the relief of disease symptoms since ancient times ${ }^{[1]}$. As a result of many years of struggle against various illnesses, humans learned to pursue drugs in barks, seeds, leaves, fruits and other plant parts ${ }^{[2]}$. It has been estimated that $25 \%$ of modern medicines are made from traditionally used plants and about $80 \%$ of the world population relies on herbal medicines in dealing with some aspects of their primary health care ${ }^{[3]}$. To establish a concrete claim on their beneficial uses, these plants have become subjects of many research studies. Among the plants of interest is Caesalpinia pulcherrima (L.) Swartz (CP), locally known in the Philippines as Bulaklak nang Paraiso. The genus Caesalpinia has more than 500 species distributed worldwide ${ }^{[4]}$. It belongs to the legume family, Fabaceae. Folkloric medicinal or herbal benefits from the different parts of $\mathrm{CP}$ are known in many parts of the world, which includes as purgative and emmenagogue in the Philippines ${ }^{[5]}$, tonic, stimulant and cathartic in India ${ }^{[6]}$, and as remedies for pyrexia, menoxenia, wheezing, bronchitis and malarial

*Address for correspondence E-mail: gtdelatorre@up.edu.ph

January-February 2017 infections in Taiwan ${ }^{[7]}$. With its many uses, researches directed towards $\mathrm{CP}$ are necessary to identify bioactive molecules that will back-up its purported medicinal capacities.

The Fabaceae family is the second largest family of medicinal plants being used as traditional medicine ${ }^{[8]}$. Several studies have proven that plants from the Fabaceae family have strong antioxidant potentials ${ }^{[8-10]}$. Antioxidants are microconstituents that inhibit lipid oxidation through prevention of the initiation or propagation of oxidizing chain reactions ${ }^{[11]}$, suppress the formation of reactive oxygen species, and inhibit enzymes or chelate elements involved in free radical production and scavenge reactive species ${ }^{[12]}$. These

This is an open access article distributed under the terms of the Creative Commons Attribution-NonCommercial-ShareAlike 3.0 License, which allows others to remix, tweak, and build upon the work non-commercially, as long as the author is credited and the new creations are licensed under the identical terms

Accepted 22 January 2017

Revised 12 November 2016

Received 27 June 2016

Indian J Pharm Sci 2017;79(1): 113-123 
mechanisms of action are necessary in cell protection, thus contributing to the prevention of cardiovascular diseases, cancer and other chronic diseases ${ }^{[13,14]}$. The search for natural antioxidant compounds has been intensified in recent years due to the reported data that synthetic antioxidants are dangerous to human health ${ }^{[15]}$. In addition, natural-based compounds are inherently better tolerated by the body than synthetic compounds ${ }^{[16]}$.

The present work aimed to provide detailed antioxidant activities of the CP leaf, flower and seed methanol extracts, expressed as half maximal inhibitory concentration $\left(\mathrm{IC}_{50}\right)$ and the establishment of correlation between their total phenolic, flavonoid and triterpenoid contents. Thin layer chromatographic (TLC) profiles of the methanol extracts were constructed. Moreover, it is also the objective of the present study to identify the antioxidant compounds present on each plant part using ultra-performance liquid chromatography quadrupole time-of-flight mass spectrometry (UPLC-QTOF/MS).

\section{MATERIALS AND METHODS}

The leaves, flowers and seeds of CP were collected from the province of Batangas, Philippines. The authentication of the plant samples was done by the Botany Division of the National Museum of the Philippines under voucher specimen no. 16-06-578.

\section{Crude methanol extraction:}

The leaves, flowers and seeds of CP were washed thoroughly, air-dried and milled. The plant samples were placed separately in an Erlenmeyer flask and macerated with methanol for $3 \mathrm{~d}$, with intermittent shaking on the first day. The macerated samples were filtered and the filtrates were concentrated in vacuo at a maximum temperature of $40^{\circ}$ using rotary evaporator. The concentrates were transferred to evaporating dishes and allowed to evaporate to dryness on a water bath. The crude methanol extracts were collected, placed on amber-bottle containers and stored at $4^{\circ}$ for future use.

\section{Dot-blot antioxidant screening:}

The semi-quantitative antioxidant screening using dotblot was based on the procedure of Huang et al. ${ }^{[17]}$. Five concentrations $(12.5,25,50,100$ and $200 \mu \mathrm{g} /$ $\mathrm{ml}$ ) were prepared from $500 \mu \mathrm{g} / \mathrm{ml}$ stock solution of crude extracts using methanol as diluent. Aliquots $(3 \mu \mathrm{l})$ were carefully loaded in order of decreasing concentration along a row onto a TLC plate and allowed to dry. The plates were placed upside down for $10 \mathrm{~s}$ in a $0.4 \mathrm{Mm}$ 2,2-diphenyl-1-picrylhydrazyl (DPPH) solution and the excess solution was removed by air-drying. A white spot on a purple background of the stained silica plate indicates the location where the radical scavenging activity appeared. The intensity of the white colour depends on the amount and nature of radical scavenger present in the sample. Ascorbic acid was used as a reference compound for the assessment of semi-quantitative antioxidant property.

\section{DPPH radical scavenging assay:}

The method was adapted from Yen and Chen ${ }^{[18]}$ with slight modifications. The samples were dissolved in methanol at various concentrations $(50,100,200$, 400 and $800 \mu \mathrm{g} / \mathrm{ml})$ and treated with DPPH (1 mM in methanol). The mixtures were left to stand for $30 \mathrm{~min}$ at room temperature in the dark. Absorbance was measured at $517 \mathrm{~nm}$ against a blank using a spectrophotometer. Ascorbic acid was used as the reference standard and the reaction without samples was used as control. The ability of the samples to scavenge DPPH radical was calculated using the Eqn. given below and expressed as $\mathrm{IC}_{50}(\mu \mathrm{g} / \mathrm{ml})$, the concentration required to scavenge $50 \%$ of DPPH radicals. DPPH radical scavenging activity $(\%)=(($ Ac-As $) / A c) \times 100$, where Ac was the absorbance of the control and As was the absorbance of the test sample.

\section{Hydrogen peroxide $\left(\mathrm{H}_{2} \mathrm{O}_{2}\right)$ scavenging assay:}

The scavenging activity of the extracts against $\mathrm{H}_{2} \mathrm{O}_{2}$ was measured based on the method of Delpour et al. ${ }^{[19]}$ with minor modifications. A solution of $40 \mathrm{mM} \mathrm{H}_{2} \mathrm{O}_{2}$ was prepared in phosphate buffer $(0.1 \mathrm{M}, \mathrm{pH}=7.4)$. Then, $1.4 \mathrm{ml}$ of different concentrations $(50,100,200$, 400 and $800 \mu \mathrm{g} / \mathrm{ml}$ ) of the crude extracts was added to $0.6 \mathrm{ml}$ of the $\mathrm{H}_{2} \mathrm{O}_{2}$ solution. The assay mixture was allowed to stand for $10 \mathrm{~min}$ at room temperature and the absorbance was measured against a blank solution at $230 \mathrm{~nm}$. Ascorbic acid was used as the reference standard and the reaction without samples was used as control. The scavenging activity was estimated on the percentage of $\mathrm{H}_{2} \mathrm{O}_{2}$ scavenged using the equation given below and expressed as $\mathrm{IC}_{50}(\mu \mathrm{g} / \mathrm{ml})$, the concentration required to scavenge $50 \%$ of $\mathrm{H}_{2} \mathrm{O}_{2} \cdot \mathrm{H}_{2} \mathrm{O}_{2}$ scavenging activity $(\%)=((\mathrm{Ac}-\mathrm{As}) / \mathrm{Ac}) \times 100$, where Ac was the absorbance of the control and As was the absorbance of the test sample.

\section{Reducing power assay:}

The ferric $\left(\mathrm{Fe}^{3+}\right)$ reducing power of the crude methanol extracts was determined using the method of Oyaizu ${ }^{[20]}$ 
with slight modifications. The extracts $(0.75 \mathrm{ml})$ of various concentration $(50,100,200,400$ and $800 \mu \mathrm{g} /$ $\mathrm{ml})$ were mixed with $0.75 \mathrm{ml}$ of phosphate buffer $(0.2$ $\mathrm{M}, \mathrm{pH}=6.6$ ) and $0.75 \mathrm{ml}$ of potassium ferricyanide $\left(\mathrm{K}_{3}\left(\mathrm{Fe}(\mathrm{CN})_{6}\right), 1 \% \mathrm{w} / \mathrm{v}\right)$, followed by incubation at $50^{\circ}$ for $20 \mathrm{~min}$. The reactions were stopped by adding $0.75 \mathrm{ml}$ of $10 \%$ trichloroacetic acid solution and the mixtures were centrifuged at $800 \mathrm{~g}$ for $10 \mathrm{~min}$. The supernatants $(1.5 \mathrm{ml})$ were mixed with $1.5 \mathrm{ml}$ of distilled water and $0.1 \mathrm{ml} \mathrm{FeCl}_{3}$ solution $(0.1 \% \mathrm{w} / \mathrm{v})$ for $10 \mathrm{~min}$. The absorbance of the reaction mixtures was measured at $700 \mathrm{~nm}$ against a blank. Ascorbic acid was used as the reference standard. The intensity of the absorbance of reaction mixtures is directly proportional to the reducing power. The antioxidant activity was expressed as $\mathrm{IC}_{50}(\mu \mathrm{g} / \mathrm{ml})$, the concentration required to have an absorbance of 0.5 .

\section{Total phenolic content:}

The total phenolic content of each extract was determined by the Folin-Ciocalteu method as described by Madaan et al. ${ }^{[21]}$ with slight modifications. The extracts $(800 \mu \mathrm{g} / \mathrm{ml}, 1 \mathrm{ml})$ were mixed with $10 \mathrm{ml}$ distilled water, added with $1.5 \mathrm{ml}$ Folin-Ciocalteu reagent and incubated for $5 \mathrm{~min}$ at room temperature. Four $\mathrm{ml}$ of $20 \% \mathrm{Na}_{2} \mathrm{CO}_{3}$ was added, adjusted with distilled water up to $25 \mathrm{ml}$ mark of the volumetric flask, agitated and left for $30 \mathrm{~min}$ at room temperature. Absorbance was read at $765 \mathrm{~nm}$ in a spectrophotometer against a blank. Total phenolic content was determined as $\mu \mathrm{g}$ gallic acid equivalent (GAE) per mg of dry extract computed from the standard calibration curve of gallic acid.

\section{Total flavonoid content:}

The determination of total flavonoid content followed the $\mathrm{AlCl}_{3}$ colorimetric method as described by Khodaie et al. ${ }^{[22]}$ with slight modifications. The extracts $(800 \mu \mathrm{g} /$ $\mathrm{ml}, 0.5 \mathrm{ml}$ ) were mixed with $2 \mathrm{ml}$ of distilled water and $150 \mu 1$ of $5 \% \mathrm{NaNO}_{2}$ solution. After 6 min of incubation, $150 \mu \mathrm{l}$ of $\mathrm{AlCl}_{3}$ solution was added, followed by $2 \mathrm{ml}$ of $1 \mathrm{M} \mathrm{NaOH}$. The mixtures were allowed to stand for 15 min at room temperature and absorbance was measured at $510 \mathrm{~nm}$ against a blank. The total flavonoid content was expressed as $\mu$ g quercetin equivalent (QE) per $\mathrm{mg}$ of dry extract computed from the standard calibration curve of quercetin.

\section{Total triterpenoid content:}

The methods of Wei et al. ${ }^{[23]}$ was followed with modifications. Briefly, after a $200 \mu 1$ sample solution in a test tube was heated to evaporation in a water bath, $1 \mathrm{ml}$ of newly mixed 5\% vanillin-acetic acid solution and $1.8 \mathrm{ml} \mathrm{H}_{2} \mathrm{SO}_{4}$ were added, mixed and incubated at $70^{\circ}$ for $30 \mathrm{~min}$. Then, the mixed solution was cooled and transferred to a volumetric flask and diluted to 10 $\mathrm{ml}$. The absorbance was measured at $573 \mathrm{~nm}$ against a blank using a spectrophotometer. The total triterpenoid contents were expressed as $\mu \mathrm{g}$ ursolic acid equivalent (UAE) per mg of dry extract computed from a standard calibration curve of ursolic acid.

\section{TLC profiling:}

The crude methanol extracts of $\mathrm{CP}$ were subjected to normal phase TLC. An exploratory phase was performed to determine the appropriate solvent system and the concentration of the extracts to be used for the maximum separation of compound-containing spots. The solvent system chosen was composed of ethyl acetate:hexane:acetic acid (70:30:1) with silica gel precoated plates as stationary phase. The extracts were dissolved in methanol to achieve a concentration of 5 $\mathrm{mg} / \mathrm{ml}$. The sample $(4 \mu \mathrm{l})$ was spotted onto the plates and allowed to run in a TLC chamber saturated with the solvent system. Daylight, UV $366 \mathrm{~nm}$ light and DPPH stain were used as visualization techniques. To qualitatively screen which spots possess antioxidant activity, the plates were dipped upside down for $10 \mathrm{~s}$ in a $0.4 \mathrm{mM}$ DPPH solution. Chromatograms producing a whitish spot on a purple background were considered to contain antioxidant activity. The $R_{f}$ values of the spots on each visualization technique were computed.

\section{UPLC-QTOF/MS analysis:}

The spots on each extract that showed antioxidant activities observed in the TLC profiling were scraped from the plates. They were separately extracted with methanol and centrifuged at $3000 \mathrm{~g}$ for $5 \mathrm{~min}$. The supernatant was collected, filtered using a $0.2 \mu \mathrm{m}$ syringe filter and then used for the identification of metabolites present. The UPLC-QTOF/MS analysis was performed on Waters Acquity UPLC I-Class/ Xevo with Xevo G2-XS QTOF mass spectrometer (MS). Five microlitres of samples were injected and separated on a $2.1 \times 100 \mathrm{~mm}$ i.d., $1.8 \mu \mathrm{m}$, Waters HSS T3 C18 column, with column temperature of $40^{\circ}$. The mobile phase was consisted of acetonitrile $+0.1 \%$ formic acid (A) and water $+0.1 \%$ formic acid (B). A $0.4 \mathrm{ml} / \mathrm{min}$ gradient was initiated with $5 \% \mathrm{~A}$ for 0.5 min, linearly increased to $95 \%$ A for $10 \mathrm{~min}$, followed by an isocratic phase for $4.5 \mathrm{~min}$. Next, the gradient 
was linearly increased to $99 \%$ A for 2.5 min and then linearly decreased to $5 \%$ A for $2.5 \mathrm{~min}$.

The Waters Xevo G2-XS QTOF MS ${ }^{\mathrm{E}}$ mode was run in a positive ion mode, with capillary voltage set at $1.0 \mathrm{kV}$, cone voltage of $40 \mathrm{~V}$, cone gas flow at 40 $1 / \mathrm{h}$, desolvation temperature of $550^{\circ}$, desolvation gas flow at $950 \mathrm{l} / \mathrm{h}$ and source temperature of $120^{\circ}$. The samples were scanned at a range of 100-1200 m/z with scan time of $0.150 \mathrm{~s}$. Leucine-enkephalin was used as reference for mass correction. The data were processed using the UNIFI Scientific Information System with the Traditional Chinese Medicine Library to identify the putative compounds present in the extracts.

\section{Statistical analysis:}

All experimental results were analysed using SPSS 17.0 software. The data were presented as mean \pm SD of three parallel measurements. One-way analysis of variance (ANOVA) followed by Tukey's post hoc test was applied to determine the differences among the antioxidant activities of the different plant parts and reference standard. Pearson's correlation coefficient between $\mathrm{IC}_{50}$ values of each antioxidant assay and total phenolic, flavonoid and triterpenoid contents were also determined. Probability values less than $0.05(\mathrm{P}<0.05)$ were regarded as significant.

\section{RESULTS AND DISCUSSION}

Semi-quantitative determination of the antioxidant capacity of each crude methanol extract was visually detected by dot-blot method. Each diluted sample was applied as a dot on the TLC plate and afterwards stained with DPPH solution (fig. 1). Faint white spots, which appeared on the $25 \mu \mathrm{g} / \mathrm{ml}$ of ascorbic acid and $\mathrm{CP}$ leaf extract corresponds to an absolute amount of $0.075 \mu \mathrm{g}$. CP flower and seed extract exhibited faint white spots at the dilution of $50 \mu \mathrm{g} / \mathrm{ml}$ equivalent to an absolute amount of $0.15 \mu \mathrm{g}$. Among the crude methanol extracts, the leaf extract produced the highest intensity of white spot at $200 \mu \mathrm{g} / \mathrm{ml}$, indicating the greatest antioxidant activity.

DPPH free radical scavenging assay is the simplest method for evaluating the antioxidant potential of an extract ${ }^{[24]}$, which is based on the electron-transfer that produces a violet solution ${ }^{[25]}$. This free radical, stable at room temperature, is reduced in the presence of an antioxidant molecule, giving rise to a colourless solution $^{[26]}$. With this method, the determination of antiradical power of an antioxidant is possible by measuring the decrease in absorbance of DPPH at 517 $\mathrm{nm}^{[27]}$.
Three extracts of CP were subjected to DPPH radical scavenging assay. All extracts showed antioxidant activity which, in the present case, is directly proportional to the concentration (fig. 2A). At 800 $\mu \mathrm{g} / \mathrm{ml}$, CP leaf extract $(\mathrm{P}>0.05)$ exhibited the highest activity among the extracts, comparable to the reference compound, ascorbic acid. It also showed the lowest $\mathrm{IC}_{50}$ value $(10.46 \pm 2.13 \mu \mathrm{g} / \mathrm{ml})$ (Table 1$)$, which denotes the highest antioxidant activity among the three extracts. A low $\mathrm{IC}_{50}$ value indicates high antioxidant activity ${ }^{[28]}$.

At low concentration levels in the air, water, plant, microorganisms, food and human body, $\mathrm{H}_{2} \mathrm{O}_{2}$ occurs naturally ${ }^{[29]}$. It can be formed in vivo by various oxidizing enzymes such as superoxide dismutase and can permeate through biological membranes slowly oxidizing a number of compounds ${ }^{[30]}$. Although $\mathrm{H}_{2} \mathrm{O}_{2}$ itself is not very reactive, it can be rapidly decomposed into oxygen and water, which may produce hydroxyl radicals that can initiate lipid peroxidation and cause DNA damage ${ }^{[31]}$. Thus, scavenging $\mathrm{H}_{2} \mathrm{O}_{2}$ is an important mechanism of antioxidants in protecting the body. The principle in $\mathrm{H}_{2} \mathrm{O}_{2}$ scavenging assay is based on the decay or loss of $\mathrm{H}_{2} \mathrm{O}_{2}$ when incubated with a scavenger ${ }^{[32]}$, whereby a decrease in absorbance occurs upon oxidation.

The scavenging capacities of $\mathrm{H}_{2} \mathrm{O}_{2}$ by $\mathrm{CP}$ extracts along with the reference standard are shown in (fig. 2B). All extracts were capable of scavenging $\mathrm{H}_{2} \mathrm{O}_{2}$ in a dosedependent manner. However, only the $\mathrm{CP}$ leaf extract at a concentration of $800 \mu \mathrm{g} / \mathrm{ml}$ exhibited comparable scavenging activity to the reference compound, ascorbic acid $(\mathrm{P}>0.05)$. As shown in Table 1, it also has the lowest $\mathrm{IC}_{50}$ value $(26.44 \pm 3.40 \mu \mathrm{g} / \mathrm{ml})$.

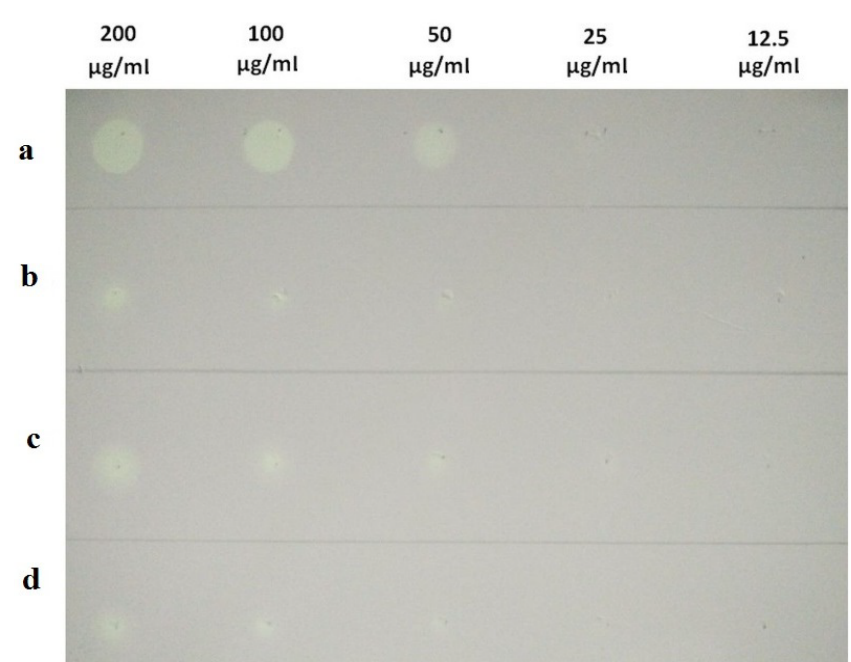

Fig. 1: Dot-blot assay of Caesalpinia pulcherrima methanol extracts and ascorbic acid

a. Ascorbic acid; b. C. pulcherrima flowers; c. C. pulcherrima leaves; d. $C$. pulcherrima seeds 

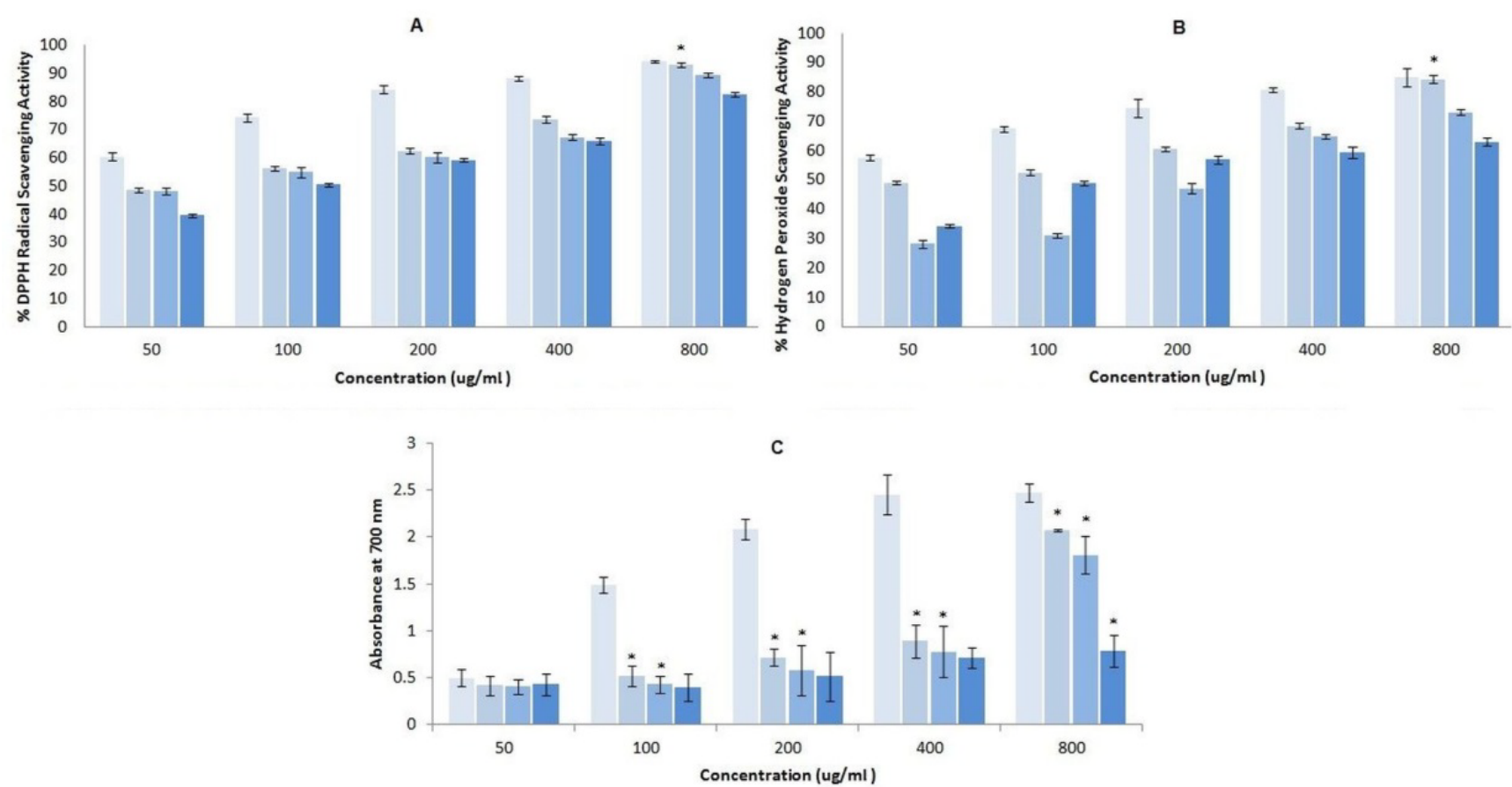

Fig. 2: Scavenging and reducing power activity of Caesalpinia pulcherrima methanol extracts and ascorbic acid Percentage DPPH radical scavenging activity (A), hydrogen peroxide scavenging activity (B) and reducing power activity (C) of Caesalpinia pulcherrima methanol extracts and ascorbic acid (reference standard). *Corresponds to values that are not significantly

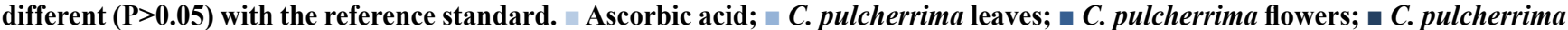
seeds

TABLE 1: ANTIOXIDANT ACTIVITIES AND TOTAL PHENOLIC, FLAVONOID AND TRITERPENOID CONTENTS OF CAESALPINIA PULCHERRIMA METHANOL EXTRACTS

\begin{tabular}{lccc}
\hline Assays & Leaf extract & Flower extract & Seed extract \\
\hline DPPH radical scavenging assay $\left(\mathrm{IC}_{50}\right)$ & $10.46 \pm 2.13$ & $38.92 \pm 0.47$ & $123.30 \pm 2.97$ \\
$\mathrm{H}_{2} \mathrm{O}_{2}$ scavenging assay $\left(\mathrm{IC}_{50}\right)$ & $26.44 \pm 3.40$ & $328.96 \pm 1.77$ & $225.34 \pm 0.76$ \\
Reducing power assay $\left(\mathrm{IC}_{50}\right)$ & $113.46 \pm 0.48$ & $147.45 \pm 0.51$ & $163.00 \pm 1.74$ \\
Total phenolic content $(\mu \mathrm{g} \mathrm{GAE} / \mathrm{mg})$ & $270.38 \pm 7.85$ & $231.92 \pm 2.79$ & $125.14 \pm 2.36$ \\
Total flavonoid content $(\mu \mathrm{g} \mathrm{QE} / \mathrm{mg})$ & $170.11 \pm 6.46$ & $82.26 \pm 4.46$ & $72.77 \pm 0.51$ \\
Total triterpenoid content $(\mu \mathrm{g} \mathrm{UAE} / \mathrm{mg})$ & $211.69 \pm 4.62$ & $50.16 \pm 5.55$ & $218.36 \pm 6.41$ \\
\hline
\end{tabular}

$\mathrm{IC}_{50}$ is half maximal inhibitory concentration. Assay is reported as mean \pm standard deviation for $\mathrm{n}=3$ observations. GAE is gallic acid equivalent, $\mathrm{QE}$ is quercetin equivalent, UAE is ursolic acid equivalent

Ferric reduction is often used as an indicator of electron donating activity, which is an important mechanism of antioxidant action ${ }^{[33]}$. The reducing ability demonstrates antioxidant action by donating hydrogen atom to break the free radical chain reaction ${ }^{[34]}$. In the assay, the yellow colour of the test solution changes to green depending on the reducing power of the sample. The presence of reductants in the sample promotes the reduction of $\mathrm{Fe}^{3+} /$ ferricyanide complex to $\mathrm{Fe}^{2+}$ which can be monitored by absorbance measurement ${ }^{[35]}$. The reducing ability, which signifies antioxidant activity, is directly proportional to the absorbance measurement.

Like the scavenging assays, all extracts possess potent antioxidant activity as displayed by their reductive ability. The reducing power increases with increasing concentration of samples (fig. 2C). The CP seed extract at $800 \mu \mathrm{g} / \mathrm{ml}$, and the CP leaf and flower extracts from 100 to $800 \mu \mathrm{g} / \mathrm{ml}$ were comparable to that of the reference compound, ascorbic acid $(\mathrm{P}>0.05)$. Similar from other antioxidant assays, the $\mathrm{CP}$ leaf extract has the lowest $\mathrm{IC}_{50}$ value $(113.46 \pm 0.48 \mu \mathrm{g} / \mathrm{ml})$, as shown in Table 1.

The total phenolic, flavonoid and triterpenoid contents were computed using gallic acid, quercetin and ursolic acid calibration curves, respectively. As shown in Table 1, the CP leaf extract has the highest amount of phenolic compounds and flavonoids, while the seed extract has the highest amount of triterpenoids. In this study, correlations between the total phenolic, flavonoid, triterpenoids and antioxidant activities $\left(\mathrm{IC}_{50}\right)$ 
were determined using Pearson's correlation test. Most of the correlations between the phytochemicals and $\mathrm{IC}_{50}$ values on each antioxidant activity assay were negative (Table 2). The flavonoid content of the CP leaf $(\mathrm{r}=$ $0.997)$ and flower $(r=0.998)$ extracts revealed a strong significant negative correlation to the $\mathrm{IC}_{50}$ values from reducing power assay. Moreover, the triterpenoid content of the CP flower ( $\mathrm{r}=-1.000)$ extract also has a strong significant negative correlation to the $\mathrm{IC}_{50}$ value from the DPPH assay. The findings indicate that the antioxidant activities of the $\mathrm{CP}$ extracts may be related, at least in part, to the presence of high flavonoid and triterpenoid compounds. The antioxidant action of flavonoid is suggested to be mainly on its reductive ability by breaking the radical chain reaction while triterpenoids are implied to acts as radical scavengers.

TLC profiling is an important tool in the quality control, isolation and identification of chemical markers of a particular plant species ${ }^{[36]}$. Thus, the present study presents the TLC profiles of the CP methanol extracts, which may serve as a reference for the proper identification, standardization and quality control of the plant.

TLC analysis was performed on each crude methanol extract of CP (fig. 3). Several combination of solvent system was utilized in the exploratory phase of the TLC analysis, after which, ethyl acetate:hexane:acetic acid
(70:30:1) was chosen because it provided the optimum separation of compound-containing spots. The colour and $R_{f}$ values of each compound-containing spots detected were recorded per visualization technique (Table 3). The CP flower extract produced the most number of compound-containing spots, followed by the leaf and then seed extract. Interestingly, all extracts produced two compound-containing spots that have antioxidant activity after DPPH staining. The aforementioned spots have the same colour and $\mathrm{R}_{\mathrm{f}}$ values at 0.14 and 0.29 . These suggest that identical antioxidant compounds can be found on the leaf, flower and seed of CP. These antioxidant spots can be used as a marker for the identity and purity of $\mathrm{CP}$.

With the complexity of the metabolites in plants, powerful analytical platforms, such as UPLC-QTOF/ MS, can be used to profile the metabolites. In this study, the spots with antioxidant activity from each plant part having the $R_{f}$ values of 0.14 and 0.29 were subjected to the analysis separately to determine the possible bioactive compounds present. The chromatograms of the different plant parts of $\mathrm{CP}$ are presented in fig. 4. Using the Traditional Chinese Medicine Library, the composition of the compounds present on the selected peaks was identified. As shown in Table 4, the leaves of CP contained 7 triterpenoids, 5 triterpenoid saponins and a flavonoid. Five triterpenoids, 3

TABLE 2: PEARSON'S CORRELATION COEFFICIENT $(r)$ BETWEEN THE IC ${ }_{50}$ OF THE ANTIOXIDANT ASSAYS AND THE TOTAL PHENOLIC, FLAVONOID AND TRITERPENOID CONTENTS OF CAESALPINIA PULCHERRIMA METHANOL EXTRACTS

\begin{tabular}{lccccccccc}
\hline Variables & \multicolumn{3}{c}{ Total phenolic content } & \multicolumn{3}{c}{ Total flavonoid content } & \multicolumn{2}{c}{ Total triterpenoid content } \\
\cline { 2 - 9 } & Leaves & Flowers & Seeds & Leaves & Flowers & Seeds & Leaves & Flowers & Seeds \\
\hline $\begin{array}{l}\text { DPPH assay } \\
\left(I C_{50}\right)\end{array}$ & -0.750 & -0.997 & -0.659 & -0.368 & -0.912 & -0.874 & 0.913 & $-1.000^{*}$ & 0.091 \\
$\mathrm{H}_{2} \mathrm{O}_{2}$ assay $\left(\mathrm{IC}_{50}\right)$ & -0.706 & -0.514 & -0.739 & -0.307 & -0.199 & -0.469 & 0.885 & -0.369 & 0.994 \\
$\begin{array}{l}\text { Reducing power } \\
\text { assay }\left(\mathrm{IC}_{50} \text { ) }\right.\end{array}$ & -0.923 & -0.961 & -0.774 & $-0.997^{*}$ & $-0.998^{*}$ & -0.942 & -0.403 & 0.794 & -0.606 \\
\hline
\end{tabular}

$\mathrm{IC}_{50}$ is half maximal inhibitory concentration, *means that correlation is significant at 0.05 level

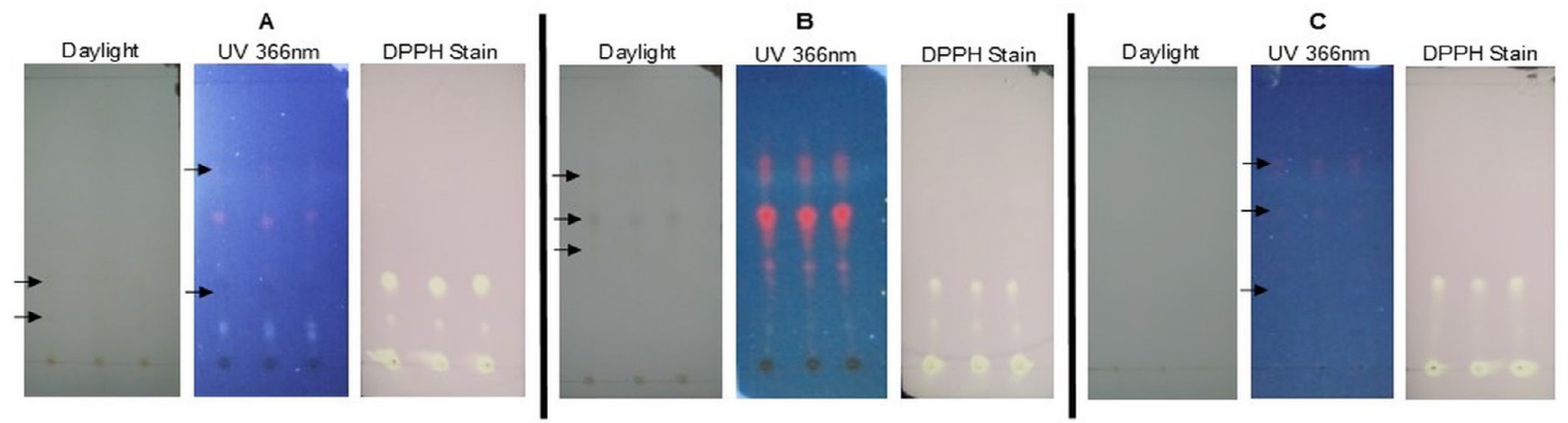

Fig. 3: TLC plates of Caesalpinia pulcherrima methanol extracts (A-leaf; B-flower; C-seed) under three visualization techniques 
TABLE 3: $R_{\mathrm{f}}$ VALUES AND COLORS OF SPOTS DETECTED UNDER EACH VISUALIZATION TECHNIQUE

\begin{tabular}{|c|c|c|c|c|c|c|}
\hline \multirow[t]{2}{*}{ Samples } & \multicolumn{2}{|c|}{ Daylight } & \multicolumn{2}{|c|}{ UV $366 \mathrm{Nm}$} & \multicolumn{2}{|c|}{ DPPH stain } \\
\hline & $R_{f}$ Value & Colour & $R_{f}$ Value & Colour & $R_{f}$ Value & Colour \\
\hline \multirow[t]{4}{*}{ Leaf extract } & 0.14 & Pale yellow & 0.14 & Light blue & 0.14 & White \\
\hline & 0.29 & Pale yellow & 0.29 & Dark blue & 0.29 & White \\
\hline & & & 0.57 & Grey & & \\
\hline & & & 0.73 & Grey & & \\
\hline \multirow[t]{6}{*}{ Flower extract } & & & 0.14 & Grey & 0.14 & White \\
\hline & & & 0.29 & Bright orange & 0.29 & White \\
\hline & & & 0.38 & Pale orange & & \\
\hline & 0.51 & Pale yellow & & & & \\
\hline & 0.53 & Grey & 0.53 & Bright orange & & \\
\hline & 0.68 & Pale yellow & 0.68 & Pale orange & & \\
\hline \multirow[t]{4}{*}{ Seed extract } & & & & & 0.14 & White \\
\hline & & & 0.29 & Light blue & 0.29 & White \\
\hline & & & 0.55 & Grey & & \\
\hline & & & 0.68 & Grey & & \\
\hline
\end{tabular}

triterpenoid saponins, 1 phenolic compound and 5 flavonoids were identified in the seeds, while the flower contains only 3 triterpenoids and 2 flavonoids. Three compounds, namely, 3-(4'-hydroxy-benzyl)-5,7dihydroxy-6,8-dimethyl-chroman-4-one, hyperforin and platycodigenin, were found to be present on the leaf, flower and seed extract.

Homoflavonoids, such as (E)-7-methoxy-3-(4'methoxybenzylidene)chroman-4-one, $(E)$-7-hydroxy3-(3',4',5'-trimethoxybenzylidene)chroman-4-one, isobonducellin, bonducellin and (E)-7-hydroxy-3(2',4'-dimethoxybenzylidene)chroman-4-one, have been reported in the whole plant of $C$. pulcherrima in India ${ }^{[37]}$. A structurally-related compound, 3-(4'-hydroxy-benzyl)-5,7-dihydroxy-6,8-dimethylchroman-4-one, has been detected in the leaves, flowers and seeds of the C. pulcherrima collected for this study. Licochalcone A, a flavonoid identified in the seeds of the plant, also has the same structure with 2'-hydroxy$2,3,4^{\prime}, 6^{\prime}$-tetramethoxychalcone, which is isolated from the aerial parts of the plant found in India ${ }^{[38]}$. These differences in the structure of the compounds under each metabolite class and the variability of metabolites present in the same species may be due to the geographical distribution and environmental conditions in which the plant thrives ${ }^{[39]}$.

Different classes of metabolites, such as triterpenoids, flavonoid and phenolic compounds, have been known to account for the antioxidant activities of plants. Triterpenoids have been reported to possess antioxidant activity by scavenging reactive oxygen species $^{[40]}$ and thus, produce beneficial effect on cardiovascular diseases, inflammation ${ }^{[41]}$ and cancer ${ }^{[42]}$. Hyperforin, a triterpenoid, demonstrated to be an effective free radical scavenger, more potent than Trolox and $\mathrm{N}$-acetylcysteine ${ }^{[43]}$. Ginsenoside $\mathrm{Rg} 2$, a triterpenoid commonly found in ginseng, has also been reported to have antioxidant properties by reducing the oxidationinduced damage of erythrocyte membrane ${ }^{[44]}$. The triterpenoid platycodigenin also showed potent antioxidant capacity against peroxynitrite, with a 2.35 fold increase in total oxidant-scavenging capacity value compared with glutathione ${ }^{[45]}$.

Phenolic compounds, including flavonoids, are considered the largest group of phytochemicals that account for most of the antioxidant activity of plants and plant products ${ }^{[46]}$. They are particularly beneficial, acting as antioxidant due to their polyphenolic nature, which enables them to donate electrons ${ }^{[47]}$ and scavenge injurious free radicals ${ }^{[48]}$. Gingerol, which is a major bioactive flavone of ginger, displayed potent antioxidant activity in a dose-dependent manner ${ }^{[49]}$ and has shown to protect HL-60 cells from oxidative stress ${ }^{[50]}$. Licochalcone A, a flavonoid, has also demonstrated potent inhibition of lipid peroxidation in rat liver microsomes compared to the reference control, butylated hydroxytoluene ${ }^{[51]}$.

Although the leaves, which have fewer identified compounds than seeds, possess the highest antioxidant activity in the in vitro antioxidant assays, this bioactivity may be accounted to the unidentified compounds as depicted by a large quantity of peaks in the chromatograms. The differences in the antioxidant capacities of the extracts could also be attributed to the qualitative variability in compounds present between the plant parts ${ }^{[52]}$. Thus, it is recommended to further 
www.ijpsonline.com
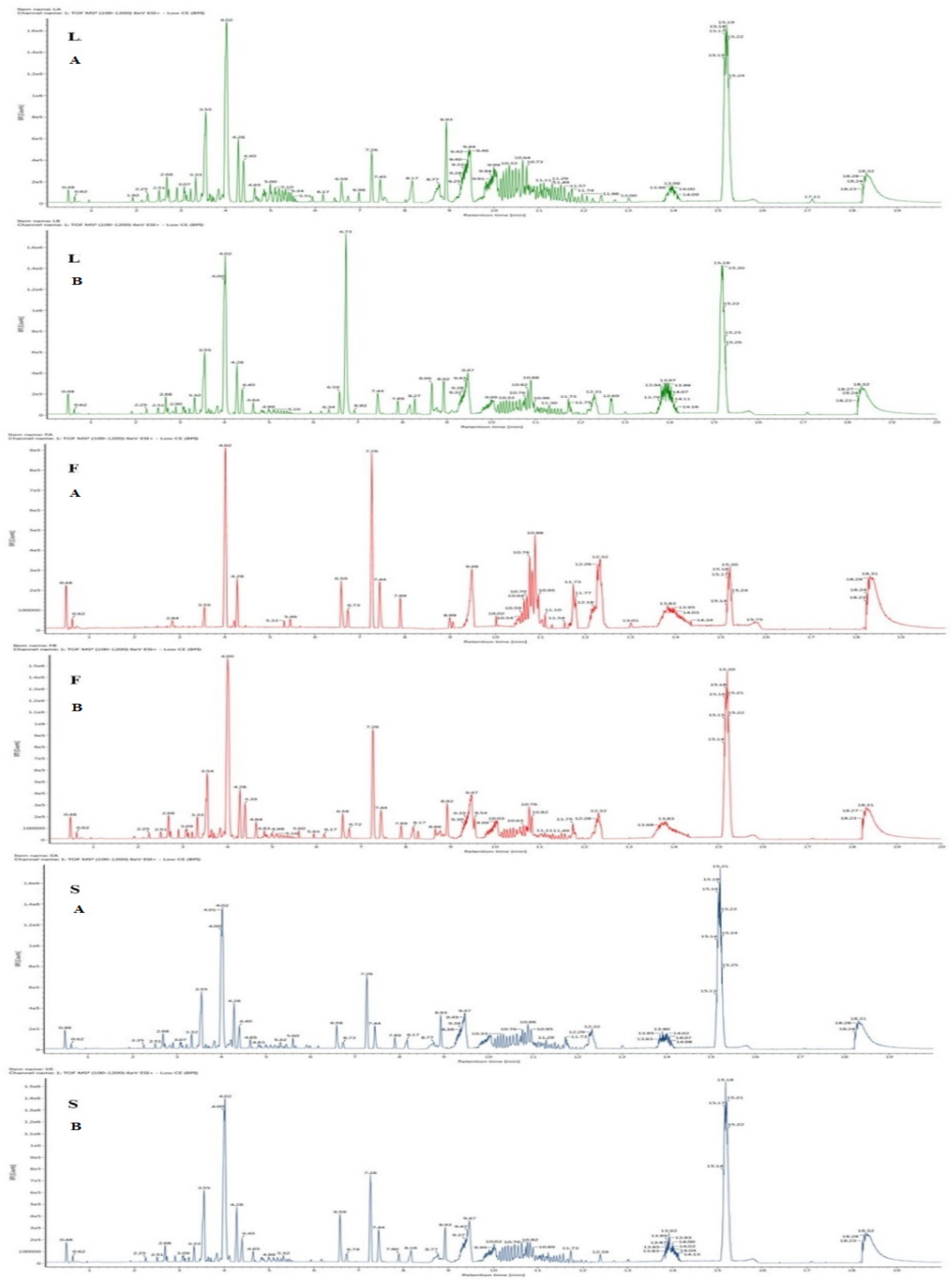

Fig. 4: Chromatograms of the spots with antioxidant activity from the different plant parts of Caesalpinia pulcherrim LA and LB-leaves, FA and FB-flowers, SA and SB-seeds; A-antioxidant spot with $R f=0.29$, B-antioxidant spot with $R f=0.14$

120 Indian Journal of Pharmaceutical Sciences

January-February 2017 
TABLE 4: METABOLITES IDENTIFIED IN THE DIFFERENT PLANT PARTS OF CAESALPINIA PULCHERRIMA USING UPLC-QTOF/MS

\begin{tabular}{|c|c|c|c|c|c|c|c|}
\hline $\begin{array}{l}\text { Compound } \\
\text { number }\end{array}$ & $\begin{array}{l}\text { Expected } \\
\text { mass }(\mathrm{Da})\end{array}$ & $\begin{array}{l}\text { Observed } \\
\text { mass }(\mathrm{Da})\end{array}$ & $\begin{array}{l}\text { Error } \\
(\mathrm{mDa})\end{array}$ & Putative compounds identified & $\begin{array}{l}\text { Metabolite } \\
\text { class }\end{array}$ & Adducts & Plant part \\
\hline$\overline{1}$ & 504.3451 & 504.3419 & -3.2053 & 12B-Hydroxycimigenol & Triterpenoid & $+\mathrm{H}$ & LA \\
\hline 2 & 680.4136 & 680.4104 & -3.1222 & $\begin{array}{l}\text { 24-O-Acetyl-cimigenol-3-O-B-D- } \\
\text { xylopyranoside }\end{array}$ & $\begin{array}{l}\text { Triterpenoid } \\
\text { saponin }\end{array}$ & $+\mathrm{Na}$ & SA \\
\hline 3 & 430.3083 & 430.3115 & 3.2185 & 25(S)-Ruscogenin & Triterpenoid & $+K$ & LA, SA, LB \\
\hline 4 & 298.1416 & 298.1415 & -0.1165 & $\begin{array}{l}\text { 2-Isopropyl-5-methyl-p- } \\
\text { hydroquinone-4-O-B-D- } \\
\text { xylopyranoside }\end{array}$ & $\begin{array}{l}\text { Triterpenoid } \\
\text { saponin }\end{array}$ & $+\mathrm{Na}$ & LA \\
\hline 5 & 314.1154 & 314.1151 & -0.3334 & $\begin{array}{c}\text { 3-(4'-Hydroxy-benzyl)-5,7- } \\
\text { dihydroxy-6,8-dimethyl-chroman- } \\
\text { 4-one }\end{array}$ & Homoflavonoid & $+\mathrm{Na},+\mathrm{K}$ & $\begin{array}{l}\text { FA, SA, } \\
F B, L B, S B\end{array}$ \\
\hline 6 & 622.4081 & 622.4063 & -1.7378 & $\begin{array}{c}\text { 3a,16a,21B,22a,28- } \\
\text { Pentahydroxyolean-12-en-28-O-B- } \\
\text { D-xylopyranoside }\end{array}$ & $\begin{array}{l}\text { Triterpenoid } \\
\text { saponin }\end{array}$ & $+\mathrm{H}$ & LA \\
\hline 7 & 634.3870 & 634.3827 & -4.2412 & $\begin{array}{c}\text { 3B-0-trans-p-Caffeoyl alphitolic } \\
\text { acid }\end{array}$ & Triterpenoid & $+\mathrm{Na}$ & LA \\
\hline 8 & 724.4398 & 724.4373 & -2.4713 & $\begin{array}{c}\text { 3-O-[a-L-Rhamnopy-ranosyl } \\
(1 \rightarrow 4)]-B-D \text {-glucopyranoside- } \\
\text { (25S)-5B-spirostan-3B-ol }\end{array}$ & $\begin{array}{l}\text { Triterpenoid } \\
\text { saponin }\end{array}$ & $+\mathrm{H}$ & $\mathrm{LB}, \mathrm{SB}$ \\
\hline 9 & 300.0634 & 300.0674 & 3.9855 & $\begin{array}{l}\text { 5,6,4'-Trihydroxy-7- } \\
\text { methoxyflavone }\end{array}$ & Flavone & $+\mathrm{H}$ & $\mathrm{SA}, \mathrm{FB}, \mathrm{SB}$ \\
\hline 10 & 294.1831 & 294.1820 & -1.1460 & 6-Gingerol & Flavone & $+\mathrm{Na}$ & SA \\
\hline 11 & 734.4605 & 734.4627 & 2.1983 & Eleutheroside $\mathrm{K}$ & $\begin{array}{l}\text { Triterpenoid } \\
\text { saponin }\end{array}$ & $+\mathrm{Na}$ & LA \\
\hline 12 & 222.0649 & 222.0649 & -3.1353 & Flavone & Flavone & $+K$ & SB \\
\hline 13 & 784.4973 & 784.4968 & -0.5421 & Ginsenoside Rg2 & $\begin{array}{l}\text { Triterpenoid } \\
\text { saponin }\end{array}$ & $+\mathrm{H}$ & SA, LB, SB \\
\hline 14 & 536.3866 & 536.3873 & 0.7429 & Hyperforin & Triterpenoid & $+\mathrm{H}$ & $\begin{array}{l}\text { SA, LA, } \\
\text { FB, LB, SB }\end{array}$ \\
\hline 15 & 338.1518 & 338.1469 & -4.9558 & Licochalcone A & Chalcone & $+\mathrm{Na}$ & SA \\
\hline 16 & 428.3654 & 428.3674 & 2.0080 & Olibanumols I & Triterpenoid & $+\mathrm{H}$ & SA, FB \\
\hline 17 & 254.1882 & 254.1841 & -4.0599 & Orientalol A & Triterpenoid & $+\mathrm{K}$ & SA, LB, SB \\
\hline 18 & 520.3400 & 520.3377 & -2.3413 & Platycodigenin & Triterpenoid & $+\mathrm{H}$ & $\begin{array}{l}\text { LA, SA, } \\
\text { FB, LB, SB }\end{array}$ \\
\hline 19 & 346.0900 & 346.0906 & 0.6425 & Polygoacetophenoside & Phenol & $+\mathrm{H}$ & SA \\
\hline 20 & 482.3396 & 482.3348 & -4.7947 & Poricoic acid C & Triterpenoid & $+\mathrm{K}$ & LA \\
\hline
\end{tabular}

$R_{f}$ is retention factor

investigate and identify these compounds through the use of other standard libraries, with the support of different analytical techniques.

\section{Financial support and sponsorship:}

Nil.

\section{REFERENCES}

1. Maqsood S, Singh P, Samoon MH, Balange AK. Effect of dietary chitosan on non-specific immune response and growth of Cyprinus carpio challenged with Aeromonas hydrophila. Inter Aqua Res 2010;2:77-85.

2. Petrovska BB. Historical review of medicinal plants' usage. Pharmacogn Rev 2012;6:1-5.

3. Zhang J, Onakpoya IJ, Posadzki P, Eddouks M. The safety of herbal medicine: from prejudice to evidence. Evid Based Complement Alternat Med 2015;2015:316706.

4. Zanin JLB, de Carvalho BA, Martineli PS, dos Santos MH,
Lago JHG, Sartorelli P, et al. The genus Caesalpinia L. (Caesalpiniaceae): phytochemical and pharmacological characteristics. Molecules 2012;17:7887-902.

5. Quisumbing E. Medicinal Plants of the Philippines. Metro Manila: Katha Publishing Co. Inc; 1978. p. 372-74.

6. Sharma V, Rajani GP. Evaluation of Caesalpinia pulcherrima Linn. For antiinflammatory and antiulcer activities. Indian J Pharmacol 2011;43:168-71.

7. Chiu NY, Chang KH. The Illustrated Medicinal Plants of Taiwan. Vol. 3. Taiwan, Republic of China: SMC Publishing Inc; 1992. p. 88.

8. Dzoyem JP, McGaw LJ, Eloff JN. In vitro antibacterial, antioxidant and cytotoxic activity of acetone leaf extracts of nine under-investigated Fabaceae tree species leads to potentially useful extracts in animal health and productivity. BMC Complement Altern Med 2014;14:147.

9. Berber A, Zengin G, Aktumsek A, Sanda MA, Uysal T. Antioxidant capacity and fatty acid composition of different parts of Adenocarpus complicates (Fabaceae) from Turkey. Rev Biol Trop 2014;62:337-46. 
10. Godevac D, Zdunic G, Savikin K, Vajs V, Menkovic N. Antioxidant activity of nine Fabaceae species growing in Serbia and Montenegro. Fitoterapia 2008;79:185-7.

11. Irshad M, Zafaryab M, Singh M, Rizvi MMA. Comparative analysis of the antioxidant activity of Cassia fistula extracts. Int J Med Chem 2012;1-6.

12. Montoro P, Braca A, Pizza C, De Tommasi N. Structureantioxidant activity relationships of flavonoids isolated from different plant species. Food Chem 2005;92:349-55.

13. Pham-Huy LA, He H, Pham-Huy C. Free radicals, antioxidants in disease and health. Int J Biomed Sci 2008;4:89-96.

14. Willcox JK, Ash SL, Catignani GL. Antioxidants and prevention of chronic disease. Crit Rev Food Sci Nutr 2004;44:275-95.

15. Lobo V, Patil A, Phatak A, Chandra N. Free radicals, antioxidants and functional foods: impact on human health. Pharmacogn Rev 2010;4:118-26.

16. Zaid H, Raiyn J, Nasser A, Saad B, Rayan A. Physicochemical properties of natural based products versus synthetic chemicals. Open Nutraceuticals J 2010;3:194-202.

17. Huang GJ, Lin YC, Deng JS, Chen HJ, Liao JC, Huang SS, et al. A novel trypsin inhibitor from sweet potato (Ipomoea batatas Lam.) leaves and its synthesized peptides with antioxidant activities in vitro. Bot Stud 2012;53:215-22.

18. Yen GC, Chen HY. Antioxidant activity of various tea extracts in relation to their antimutagenicity. J Agric Food Chem 1995;43:27-32.

19. Delpour AA, Ebrahimzadeh MA, Nabawi SF, Nabavi SM. Antioxidant activity of the methanol extract of Ferula assafoetida and its essential oil composition. Grasas Aceites 2009;60:405-12.

20. Oyaizu M. Studies on products of browning reactions: antioxidative activities of products of browning reaction prepared from glucosamine. Jpn J Nutr 1986;44:307-15.

21. Madaan R, Bansal G, Kumar S, Sharma A. Estimation of total phenols and flavonoids in extracts of Actaea spicata roots and antioxidant activity studies. Indian J Pharm Sci 2011;73:666-9.

22. Khodaie L, Bamdad S, Delazar A, Nazemiyeh H. Antioxidant, total phenol and flavonoid contents of two Pedicularis L. species from Eastern Azerbaijan, Iran. Bioimpacts 2012;2:43-57.

23. Wei L, Zhang W, Yin L, Yan F, Xu Y, Chen F. Extraction optimization of total triterpenoids from Jatropha curcas leaves using response surface methodology and evaluations of their antimicrobial and antioxidant capacities. Electron $\mathrm{J}$ Biotech 2015;18:88-95.

24. Kedare SB, Singh RP. Genesis and development of DPPH method of antioxidant assay. J Food Sci Technol 2011;48:412-22.

25. Huang DJ, Ou BX, Prior RL. The chemistry behind antioxidant capacity assays. J Agric Food Chem 2005;53:1841-56.

26. Garcia EJ, Oldoni TLC, de Alencar SM, Reis A, Loguercio AD, Grande RHM. Antioxidant activity by DPPH assay of potential solutions to be applied on bleached teeth. Braz Dent J 2012;23:22-7.

27. Govindan P, Muthukrishnan S. Evaluation of total phenolic content and free radical scavenging activity of Boerhavia erecta. J Acute Med 2013;3:103-09.

28. Farasat M, Khavari-Nejad RA, Nabavi SMB, Namjooyan F. Antioxidant activity, total phenolics and flavonoid contents of some edible green seaweeds from northern coasts of the Persian gulf. Iran J Pharm Res 2014;13:163-70.

29. Gulcin I, Berashvili D, Gepdiremen A. Antiradical and antioxidant activity of total anthocyanins from Perilla pankensis Decne. J Ethnopharmacol 2005;101:287-93.

30. Fernando CD, Soysa P. Optimized enzymatic colorimetric assay for determination of hydrogen peroxide $\left(\mathrm{H}_{2} \mathrm{O}_{2}\right)$ scavenging activity of plant extracts. Methods 2015;2:283-91.

31. Sahreen S, Khan MR, Khan RA. Phenolic compounds and antioxidant activities of Rumex hastatus D. Don. leaves. J Med Plants Res 2011;5:2755-65.

32. Kumar RS, Rajkapoor B, Perumal P. Antioxidant activities of Indigofera cassioides Rottl. Ex. DC. using various in vitro assay models. Asian Pac J Trop Biomed 2012;2:256-61.

33. Dorman HJD, Peltoketo A, Hiltunen R, Tikkanen MJ. Characterization of the antioxidant properties of deodorized aqueous extracts from selected Lamiaceae herbs. Food Chem 2003;83:255-62.

34. Gordon MH. The Mechanisms of Antioxidant Action In Vitro. In: Hudson BJF, editor. Food Antioxidants. Netherlands: Springer; 1990. p. 1-18.

35. Saeed N, Khan MR, Shabbir M. Antioxidant activity, total phenolic and total flavonoid contents of whole plant extracts Torilis leptophylla L. BMC Complement Altern Med 2012;12:221.

36. Gebrehiwot M, Asres K, Bisrat D, Mazumder A, Lindemann $\mathrm{P}$, Bucar F. Evaluation of the wound healing property of Commiphora guidotii Chiov. ex. Guid. BMC Complement Altern Med 2015;15:282-93.

37. Maheswara M, Siddaiah V, Rao CV. Two new homoisoflavonoids from Caesalpinia pulcherrima. Chem Pharm Bull 2006;54:1193-5.

38. Rao YK, Fang SH, Tzeng YM. Anti-inflammatory activities of flavonoids isolated from Caesalpinia pulcherrima. J Ethnopharmacol 2005;100:249-53.

39. Hossain MA, Shah MD. A study on the total phenols content and antioxidant activity of essential oil and different solvent extracts of endemic plant Merremia borneesis. Arab J Chem 2015;8:66-71.

40. Rosalia RR, Simonsen U. Natural Triterpenoids from Olive Oil: Potential Activities against Cancer. In: Diederich M, Noworyta K, editors. Natural Compounds as Inducers of Cell Death. Volume 1. Berlin, Germany: Springer; 2012. p. 455.

41. Han N, Bakovic M. Biologically active triterpenoids and their cardioprotective and antiinflammatory effects. J Bioanal Biomed 2015;S12:005.

42. Bishayee A, Ahmed S, Brankov N, Perloff M. Triterpenoids as potential agents for the prevention and therapy of breast cancer. Front Biosci 2011;16:980-96.

43. Meinke MC, Schanzer S, Haag SF, Casetti F, Muller ML, Wolfle $\mathrm{U}$, et al. In vivo photoprotective and antiinflammatory effect of hyperforin is associated with high antioxidant activity in vitro and ex vivo. Eur J Pharm Biopharm 2012;81:346-50.

44. Lee $\mathrm{CH}$, Kim JH. A review on the medicinal potentials of ginseng and ginsenosides on cardiovascular diseases. J Ginseng Res 2014;38:161-6.

45. Ryu CS, Kin CH, Lee SY, Lee KS, Choung KJ, Song GY, et al. Evaluation of the total oxidant scavenging capacity of saponins isolated from Platycodon grandiflorum. Food Chem 2012;132:333-7.

46. Okpuzar J, Ogbunugafor H, Kareem GK, Igwo-Ezikpe MN. In vitro investigation of antioxidant phenolic compounds in extract of Senne alata. Res J Phytochem 2009;3:68-76.

47. Das SC, Hamid K, Bulbul IJ, Sultana S, Islam S. In vitro antioxidant activity of different parts of the plant Diospyros discolor. Res J Agric Biol Sci 2010;6:472-5. 
48. Dewick PM. Medicinal Natural Products: A Biosynthetic Approach. $3^{\text {rd }}$ ed. Hoboken, NJ, USA: John Wiley and Sons; 2009. p. 150.

49. Dugasani S, Pichika MR, Nadarajah VD, Balijepalli MK, Tandra S, Korlakunta JN. Comparative antioxidant and anti-inflammatory effects of [6]-gingerol, [8]-gingerol, [10]-gingerol and [6]-shogoal. J Ethnopharmacol 2010;127:515-20.

50. Wang CC, Chen LG, Lee LT, Yang LL. Effects of 6-gingerol, an antioxidant from ginger, on inducing apoptosis in human leukemic HL-60 cells. In Vivo 2003;17:641-5.

51. Fu Y, Chen J, Li YJ, Zheng YF, Li P. Antioxidant and antiinflammatory activities of six flavonoids separated from licorice. Food Chem 2013;141:1063-71.

52. Zemmouri H, Ammar S, Boumendjel A, Messarah M, El Feki A, Bouaziz M. Chemical composition and antioxidant activity of Borago officinalis L. leaf extract growing in Algeria. Arab J Chem 2014;11:59. 